\title{
ОЦІНКА ПРОЦЕСІВ ТА МАКРОЕКОНОМІЧНИХ НАСЛІДКІВ МІЖНАРОДНОї ТРУДОВОЇ МІГРАЦІї В УМОВАХ ГЛОБАЛЬНОЇ ЕКОНОМІКИ
}

\section{ASSESSMENT OF PROCESSES AND MACROECONOMIC CONSEQUENCES OF INTERNATIONAL LABOR MIGRATION IN THE GLOBAL ECONOMY}

\author{
Македон Вячеслав Владиславович \\ доктор економічних наук, просресор, \\ Дніпровський національний університет імені Олеся Гончара \\ ORCID: https://orcid.org/0000-0001-8131-0235 \\ Makedon Vyacheslav \\ Oles Honchar Dnipro National University
}

\begin{abstract}
Стаття присвячена питанню дослідження поточних тенденцій в ссрері міжнародної трудової міграції та визначає перспективні напрямки есрективного її регулювання в межах глобальної економіки. В сучасних глобалізаційних умовах міграційні процеси набувають все більшої ролі у економічному розвитку окремих країн. Було проведено дослідження загальних світових міграційних процесів в контексті фрормування міжнародної трудової міграції та надано оцінку поточного стану міжнародної трудової міграції. Проведено аналіз нових тенденцій розвитку міжнародного ринку праці і формування міграційних потоків, що дозволило обґрунтувати глобальні виклики і регулювання процесів міжнародної трудової міграції. Практичне значення роботи пов'язано із розробкою напрямів удосконалення міграційної політики, рекомендаціями щодо спеціальних заходів та дій для швидшого досягнення орієнтирів всеохоплюючого зростання.
\end{abstract}

Ключові слова: міжнародна міграція, міжнародний ринок праці, глобальна економіка, міграційні коридори, транскордонні переміщення, вікова і статева структура міжнародних мігрантів.

Статья посвящена исследованию текущих тенденций в сорере международной трудовой миграции и определяет перспективные направления эфрфективного ее регулирования в рамках глобальной экономики. В современных глобальных условиях миграционные процессы приобретают все большую роль в экономическом развитии отдельных стран. Были проведены исследования общих мировых миграционных процессов в контексте формирования международной трудовой миграции и дана оценка текущего состояния международной трудовой миграции. Проведен анализ новых тенденций развития международного рынка труда и фрормирования миграционных потоков, что позволило обосновать глобальные вызовы и регулирование процессов международной трудовой миграции. Практическое значение работы связано с разработкой направлений усовершенствования миграционной политики, рекомендациями по специальным мерам и действиям для более быстрого достижения ориентиров всеобъемлющего роста.

Ключевые слова: международная миграция, международный рынок труда, глобальная экономика, миграционные коридоры, трансграничные движения, возрастная и половая структура международных мигрантов.

The article is devoted to the study of current trends in the field of international labor migration and identifies promising areas for effective regulation within the global economy. In the process of research a number of specific scientific methods were used: structural, functional, situational analysis, comparisons, grouping, statistical analysis, methods of analogies and expert assessments. In today's globalization, migration processes are becoming increasingly important in the economic development of individual countries. They affect the number of jobs, the overall level of employment, cash flows between countries, trade relations, and so on. Migration flows between countries are becoming more intense every year, which leads to significant changes in the structure of national labor markets. That is why today migration as an economic category is given a lot of attention. It has been identified that labor migration is an ambiguous phenomenon that can have both positive and negative consequences for countries, depending on the point of view. as they will remove the burden of unemployment in the country's economy. For countries with significant labor shortages, immigration will have a positive effect, as it will help fill vacancies. Labor migration is one of the components of labor mobility. Therefore, migration processes and labor mobility are important factors in- 
fluencing the overall economic situation of any country in the world. A study of general world migration processes in the context of the formation of international labor migration was conducted and an assessment of the current state of international labor migration was provided. The analysis of new tendencies of development of the international labor market and formation of migration flows is carried out that allowed to substantiate global challenges and regulation of processes of international labor migration. The practical significance of the work is related to the development of directions for improving migration policy, recommendations for special measures and actions to quickly achieve the goals of inclusive growth.

Keywords: international migration, international labor market, global economy, migration corridors, cross-border movements, age and gender structure of international migrants.

Постановка проблеми. Одним із проявів глобалізації як процесу всесвітньої економічної, політичної та культурної інтеграції, $€$ становлення глобального ринку праці, який фрормується і фрункціонує завдяки міжнародній міграції персоналу. Розвиток транспорту, зв'язку, унісрікація виробничих процесів та системи освіти, транснаціоналізація економічних систем дозволяють узгоджувати попит та пропозицію на персонал незалежно від країни походження працівника. Демографрічна криза в розвинутих країнах, що виявляється в скороченні кількості працездатних і збільшенні людей похилого віку, потреба у висококваліфрікованих працівниках для високотехнологічних виробництв, а також наявність великої кількості непрестижних робочих місць у сорері послуг, охороні здоров'я, будівництві, сільському господарстві тощо, на які корінні жителі йдуть неохоче, зумовлюють потребу в залученні робочої сили ззовні.

Аналіз останніх досліджень і публікацій. В загальному науковому полі питання і проблематика міжнародної міграції, трудових відносин, світового попиту на працю досліджуються в роботах як вітчизняних так і зарубіжних вчених. Найбільш цікавими є обґрунтування таких дослідників як: К. Бондаревська, Р. Вазов, В. Валіков, О. Гетьман, Л. Ємчук, Н. Короленко, В. Македон, О. Михайленко, Н. Ушенко, А. Петросян, А. Покормяк. Переважна більшість людей мігрує за кордон з причин, пов'язаних з роботою, сім'єю та навчанням, що передбачає міграційні процеси. Це свідчить про потребу в нових дослідженнях і висновках щодо цього міжнародного процесу.

Формулювання цілей статті (постановка завдання). Мета дослідження - дослідити поточні тенденції міжнародної трудової міграції та визначити напрямки ефрективного макроекономічного регулювання в межах глобальної економіки.

Виклад основного матеріалу. Міграційні кризи, що на сьогодні вирують у всьому світі і переважно пов'язані зі значною чисельністю біженців 3 країн третього світу, продукують значні міжетнічні та міжрелігійні конорлікти, поширення хвороб, зростання рівня безробіття у країнах-реципієнтах та загострення у них соціально-гуманітарних проблем забезпечення іммігрантів. Так чітко сорормувалися глобальні центр тяжіння мігрантів, це ЄС та США. Такий стан справ пояснюється дисбалансами на національних ринках праці (розширенням пропозиції робочих місць у розвинених країнах світу та їх більш стабільним інституційним середовищем) [1, с. 46]. Ми можемо заначити, що за наявними оцінками, останні п'ять десятиліть відбулося збільшення чисельності міжнародних мігрантів. Загальна оцінювана чисельність людей, які в 2020 р. проживали в країні, що не $є$ країною їх народження, що становить 272 млн осіб, на 119 млн осіб перевищила цей показник 1990 р. (коли їх налічувалося $153 \mathrm{млн} \mathrm{осіб)} \mathrm{і} \mathrm{втричі} \mathrm{оцінювану} \mathrm{чисельність}$ 1970 р. (84 млн осіб) [2] (табл. 1).

Таблиця 1

\section{Динаміка міжнародної міграції} у період 1970-2020 рр.

\begin{tabular}{|c|c|c|}
\hline періоди & $\begin{array}{c}\text { Кількість } \\
\text { мігрантів, чол. }\end{array}$ & $\begin{array}{c}\text { Мігранти у \% } \\
\text { від населення } \\
\text { світу }\end{array}$ \\
\hline 1970 & 84460125 & $2,3 \%$ \\
\hline 1975 & 90368010 & $2,2 \%$ \\
\hline 1980 & 101983149 & $2,3 \%$ \\
\hline 1985 & 113206691 & $2,3 \%$ \\
\hline 1990 & 153011473 & $2,9 \%$ \\
\hline 1995 & 161316895 & $2,8 \%$ \\
\hline 2000 & 173588441 & $2,8 \%$ \\
\hline 2005 & 191615574 & $2,9 \%$ \\
\hline 2010 & 220781909 & $3,2 \%$ \\
\hline 2015 & 248861296 & $3,4 \%$ \\
\hline 2020 & 271642105 & $3,5 \%$ \\
\hline
\end{tabular}

Джерело: [2]

Хоча за цей період у світі мало місце також збільшення частки міжнародних мігрантів, очевидно, що переважна більшість людей продовжують жити у тих країнах, де вони народилися. За нашими дослідженнями 


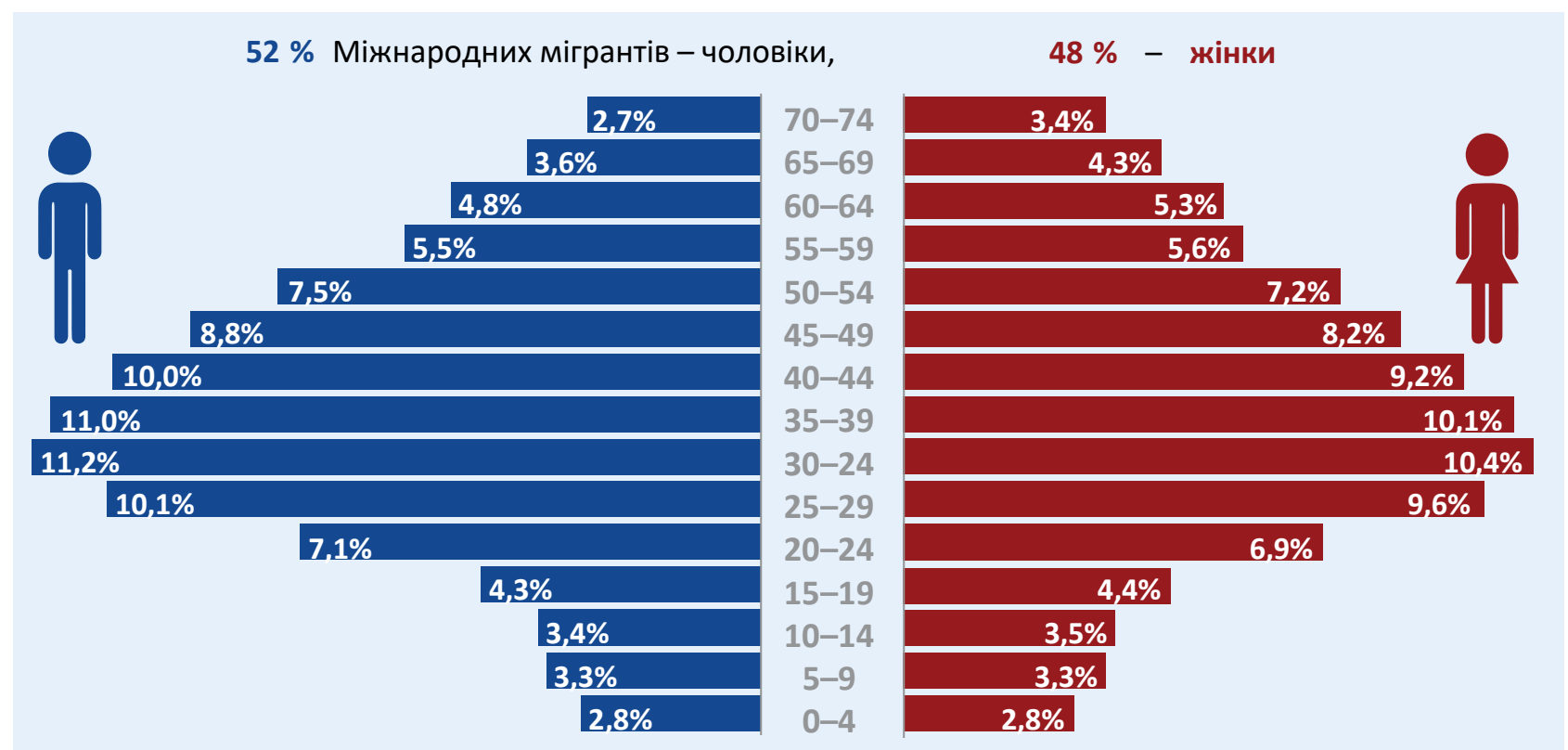

Рис. 1. Вікова і статева структура міжнародних мігрантів за підсумками 2020 р.

Джерело: [3]

У 2020 р. більшість міжнародних мігрантів (близько 74\%) перебували у працездатному віці (20-64 роки), причому за період 2000-2020 рр. частка мігрантів молодше 20 років зменшилася (з 16,4\% до 14\%) за збереження незмінної з 2000 р. частки міжнародних мігрантів у віці 65 років і більше (близько 12\%) [2] (рис. 1).

У 2020 р. Європа та Азія приймали відповідно 82 млн і 84 млн міжнародних мігрантів, які становили 61\% загального світового сукупного контингенту міжнародних мігрантів. За цими регіонами слідували Північна Америка, в якій у 2020 р. налічувалося майже 59 млн міжнародних мігрантів, або 22\% від глобального контингенту мігрантів, Африка - 10\%, Латинська Америка та Карибський басейн 4\% та Океанія - 3\%. У порівнянні з чисельністю населення в кожному регіоні частка міжнародних мігрантів у 2020 р. була найвищою в Океанії, Північній Америці та Європі, де міжнародні мігранти становили відповідно 21\%, 16\% та 11\% від загального населення. Порівняно з ними частка міжнародних мігрантів відносно невелика в Азії та Афрриці (відповідно, 1,8\% та 2\%) та у Латинській Америці та Карибському басейні (1,8\%). Однак, у період 2000-2020 років в Азії спостерігався найбільш значний приріст мігрантів - 69\% (близько 34 млн осіб) [4]. У цей же період у Європі відзначався другий за величиною приріст чисельності міжнародних мігрантів, що становив 25 млн осіб, за якою слідували Пів- нічна Америка - 18 млн та Афррика - 11 млн міжнародних мігрантів [5; 6] (рис. 2).

Згодом зростання міжнародної міграції у деяких регіонах вплинув зміну чисельності населення. На рис. 3. показано пропорційну динаміку чисельності населення в кожному із шести регіонів світу з 2009 по 2020 рр.

Хоча Європа традиційно була одним із основних регіонів призначення для міжнародних мігрантів, у ній протягом цього періоду спостерігалася найнижчі темпи пропорційної зміни чисельності населення - трохи більше 1\%. Однак можна стверджувати, що цей показник був би набагато нижчим без міжнародних мігрантів, які пом'якшили скорочення чисельності населення в деяких європейських країнах, зокрема внаслідок зниження народжуваності. Для порівняння, в Африці відбулися найбільш значні зміни: за цей період їі населення зросло майже на 30\% через високі показники народжуваності та збільшення тривалості життя. Проте цей приріст згладжувався внаслідок еміграції з Асррики до інших регіонів, а саме до Європи та Азії [5, с. 69-70].

Таким чином, зростання чисельності населення протягом десятиліття може бути найпомітнішим для Африки, у 2020 р. більше половини населення світу проживало лише в одному регіоні - в Азії (4,6 млрд осіб). У період 3 2009 р. по 2020 р. населення Азії зросло майже на 440 млн осіб (3 4,16 млрд до 4,6 млрд осіб) порівняно з трохи менше ніж 300 млн осіб в Афрриці (3 1,01 млрд до 1,31 млрд осіб). 


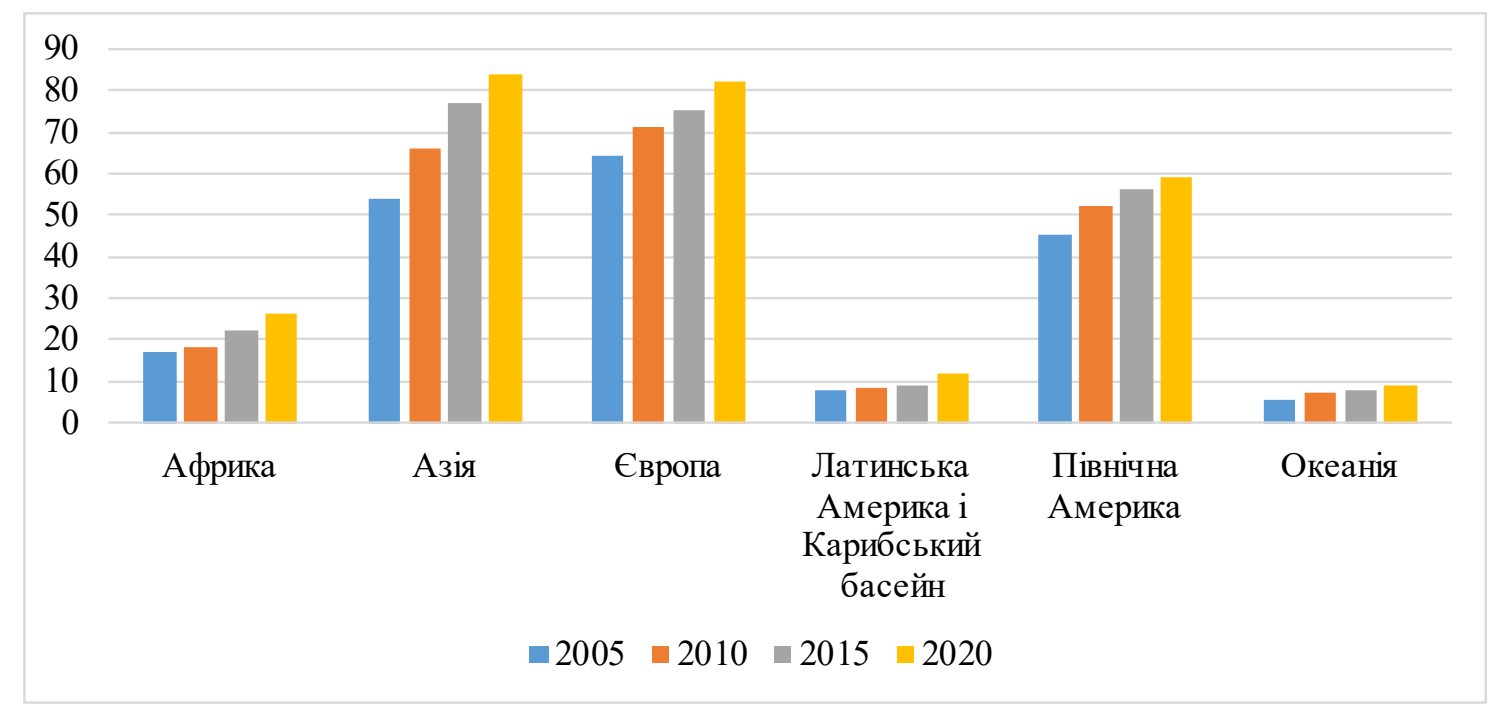

Рис. 2. Міжнародні мігранти з основних регіонів проживання, 2005-2020 рр. (у млн осіб)

Джерело: [3]

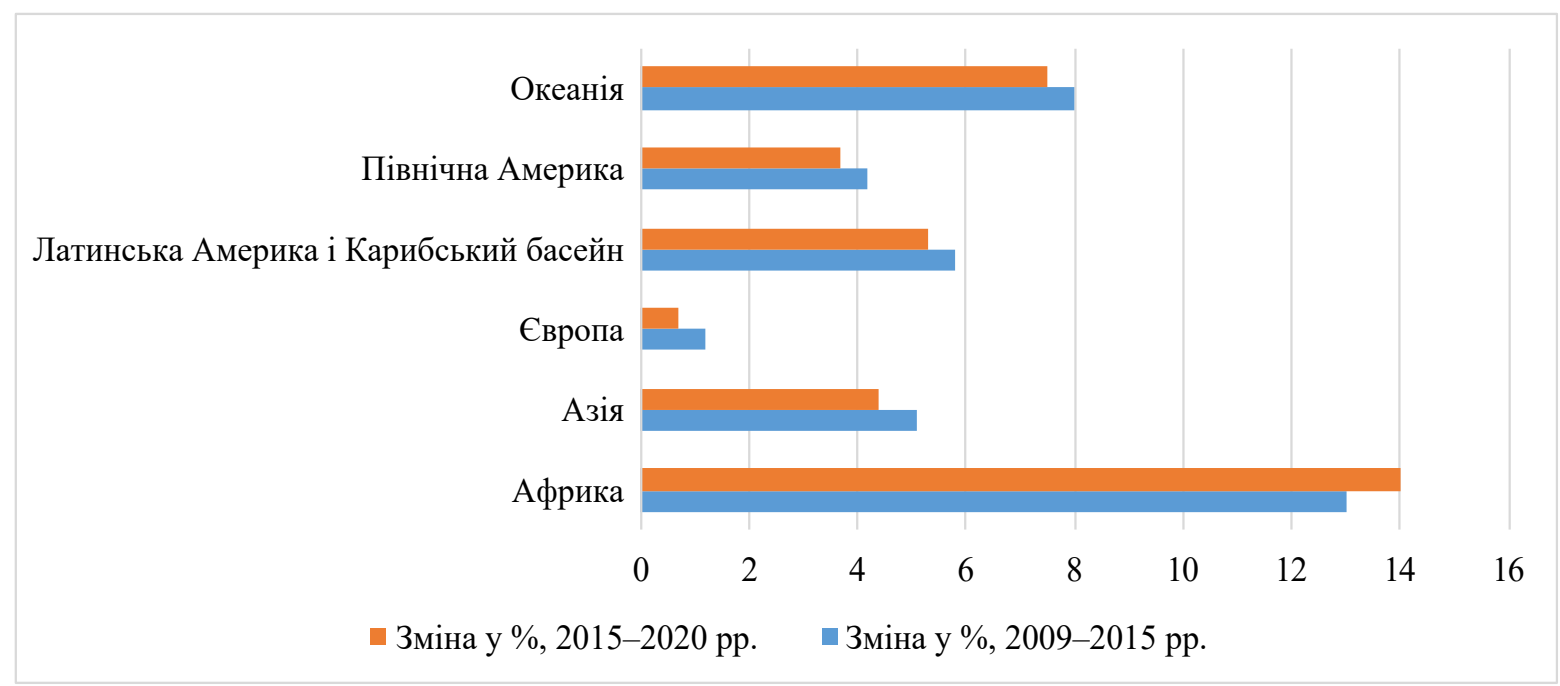

Рис. 3. Пропорційна зміна чисельності населення у регіонах, 2009-2020 рр.

Джерело: [3]

П'ять із десяти найбільш густонаселених країн світу знаходяться в Азії (Китай, Індія, Індонезія, Пакистан та Бангладеш) [2].

Станом на 2021 р. із усіх міжнародних мігрантів у світі понад 40\% (112 млн осіб) народилися в Азії, будучи вихідцями головним чином з Індії (звідки походить найбільше мігрантів), Китаю та країн Південної Азії, таких як Бангладеш, Пакистан та Асрганістан. Мексика за цим показником посідала друге місце серед країн походження, а Російська Федерація була четвертою. 3 кількох інших європейських країн походить значна кількість емігрантів, зокрема з України, Польщі, Сполученого Королівства та Німеччини [3].
Що стосується розподілу міжнародних мігрантів за групами країн 3 різними рівнями доходів, то у 2020 р. майже дві третини міжнародних мігрантів проживали в країнах з високим рівнем доходу - близько 176 млн осіб18. Порівняно 3 ними того ж року у країнах із середнім рівнем доходу проживали 82 млн мігрантів, що народилися за кордоном (близько однієї третини загального контингенту мігрантів), а в країнах $з$ низьким рівнем доходу - 13 млн таких мігрантів [4].

За оцінками ООН, обсяги міжнародної міграції продовжують зростати. У 2020 р. чисельність міжнародних мігрантів досягла 258 млн осіб, у 2010 р. їх кількість складала 
220 млн осіб, у 2000 р. - 173 млн осіб. У період з 2000 по 2005 рр. кількість міжнародних мігрантів зростала в середньому на 2\% на рік. Упродовж 2005-2010 років темпи приросту прискорилися, досягши 2,9\% на рік. 32010 р. спостерігається сповільнення темпу приросту обсягів міжнародних мігрантів, показник знаходився на рівні 2,4 \% на рік у період 2010-2015 рр. та 2,0\% на рік у період 2015-2020 рp. [6].

Аналізуючи структуру міжнародних мігрантів за їх походженням слід зазначити, що за даними 2020 р. 3258 млн міжнародних мігрантів у світі 106 млн народилися в Азії. Європа була другим регіоном походження мігрантів (61 млн осіб), за нею йде Латинська Америка та країни Карибського басейну (38 млн осіб) та Афррика (36 млн осіб). За країнами походження найбільше мігрантів у світі налічувалося: з Індії (17 млн осіб), Мексики (13 млн осіб), Росії (11 млн осіб), Китаю (10 млн осіб), Бангладешу (7 млн осіб), Сирії (7 млн осіб), Пакистану та України (по 6 млн осіб). Напрям руху міжнародних мігрантів поступово змінюється порівняно з даними початку століття [6] (рис. 4).

Найбільший трудовий міграційний приріст спостерігається між Афррикою та Північною Америкою, у період з 2000 по 2020 рр. середньорічний темп зростання кількості мігрантів 3 Асрики в США та Канаді становив 4,9\% або 1,5 млн осіб на рік. Для порівняння, в країнах
Азії зростання числа мігрантів з Афррики становило в середньому 4,2\%. Серед міграційних коридорів слід виділити зростання кількості мігрантів з Мексики до США та 3 Індії до OAE. Розрив у соціально-економічному розвитку країн призводить до того, що основні потоки мігрантів формуються з відносно невеликої кількості країн світу. Зміни у середньому віці міжнародних мігрантів $€$ порівняно незначними. Так, середній вік міжнародних мігрантів в 2020 р. становив 39 років, порівняно 3 віком 38 років у 2000 р. Слід зазначити, що в таких регіонах, як Азія, Латинська Америка та Океанія, середній вік міжнародних мігрантів знижується [7, с. 102-103].

Хоча міжнародні мігранти можуть тяжіти до країн з високим рівнем доходу, у глобальному масштабі їхнє коріння може бути різним. У деяких країнах походження висока частка їхніх громадян проживає за кордоном 3 економічних, політичних, пов'язаних 3 безпекою, торгових чи культурних причин, які можуть мати сучасний чи історичний характер. Наприклад, у Сирійській Арабській Республіці рівень еміграції вищий, ніж у більшості інших країн через переміщення, викликане тривалим конфрліктом. Важливо відзначити, що відсоток населення в еміграції відображає накопичення процесів міграції (і переміщення) $з$ часом, іноді протягом багатьох десятиліть. Приблизне географрічне розмаїття країн (включаючи країни з усіх регіонів, крім

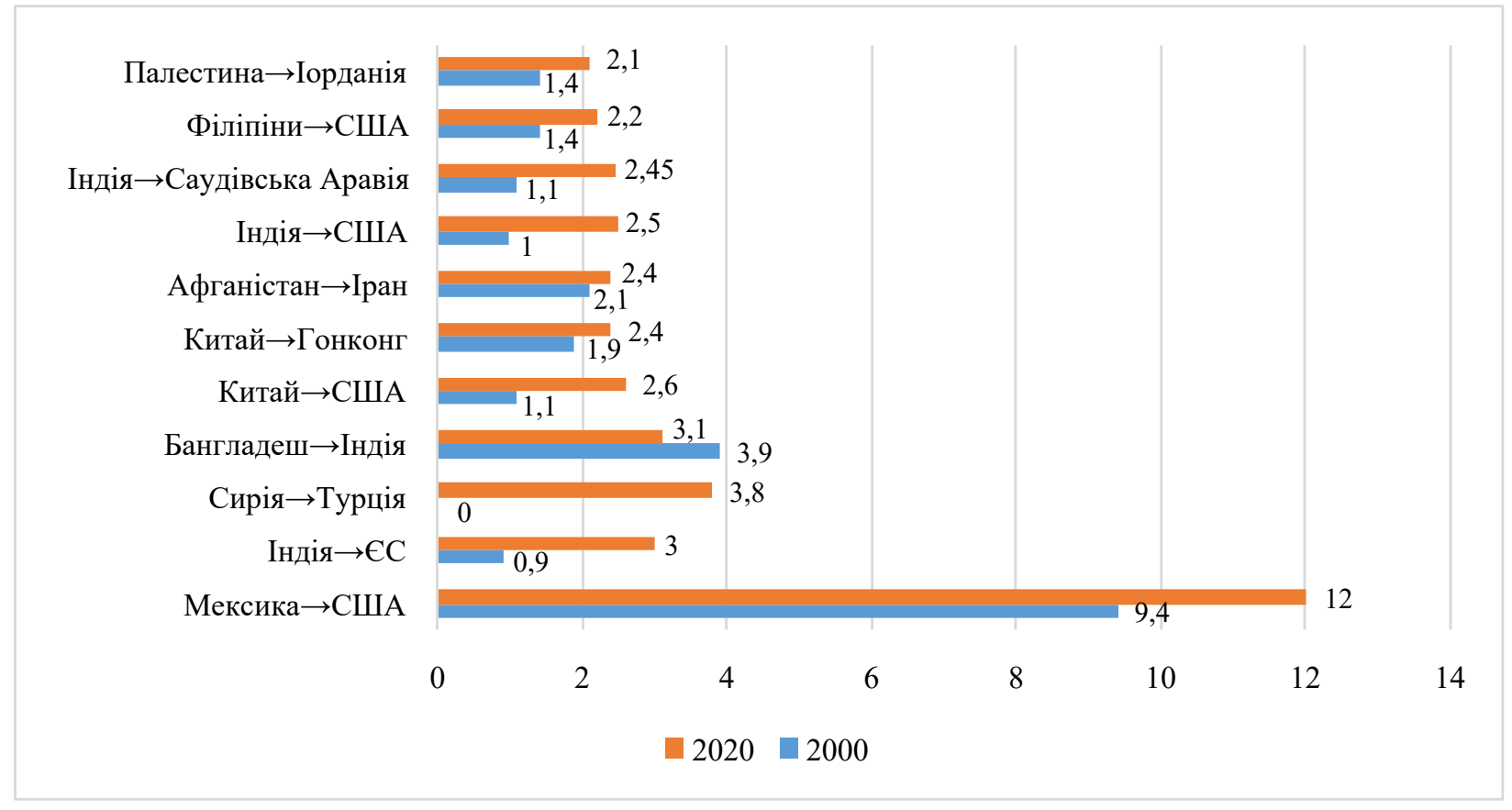

Рис. 4. Найбільші міграційні коридори у світі (порівняння 2000 та 2020 рр.), млн осіб Джерело: [6] 
Північної Америки), а також велику кількість країн 3 Латинської Америки та Карибського басейну (10 із 20 країн) [4].

Під впливом наростаючих диспропорцій у світовій економіці, демограсрічної асиметрії, політичної нестабільності, технологічної та соціальної транссрормації, нових тенденцій на міжнародному ринку праці, зростання взаємозалежності працьовитих і трудонедостатніх країн, попиту на певні категорії фрахівців (квалісрікації, компетенції, навички) розвивається до якої залучені всі країни та регіони світу, що підтверджується зростанням чисельності міжнарод- них мігрантів (за прогнозом Міжнародної організації 3 міграції до 2050 р., вона може досягти 321 млн. осіб). До середини 2020 р. воно досягло майже 272 млн. чол. (зростання на 56\%) проти 174 млн. чоловік 2000 р. [6] (рис. 5).

В даний час існує два основних міжнародні набори даних про міжнародні міграційні потоки, які обидва складаються з національних статистичних даних: Набір даних про міжнародні міграційні потоки ДЕСВ ООН та База даних про міжнародну міграцію ОЕСР. 32005 р. ДЕСВ ООН компілює дані про потоки міжнародних мігрантів в окремі країни та з них

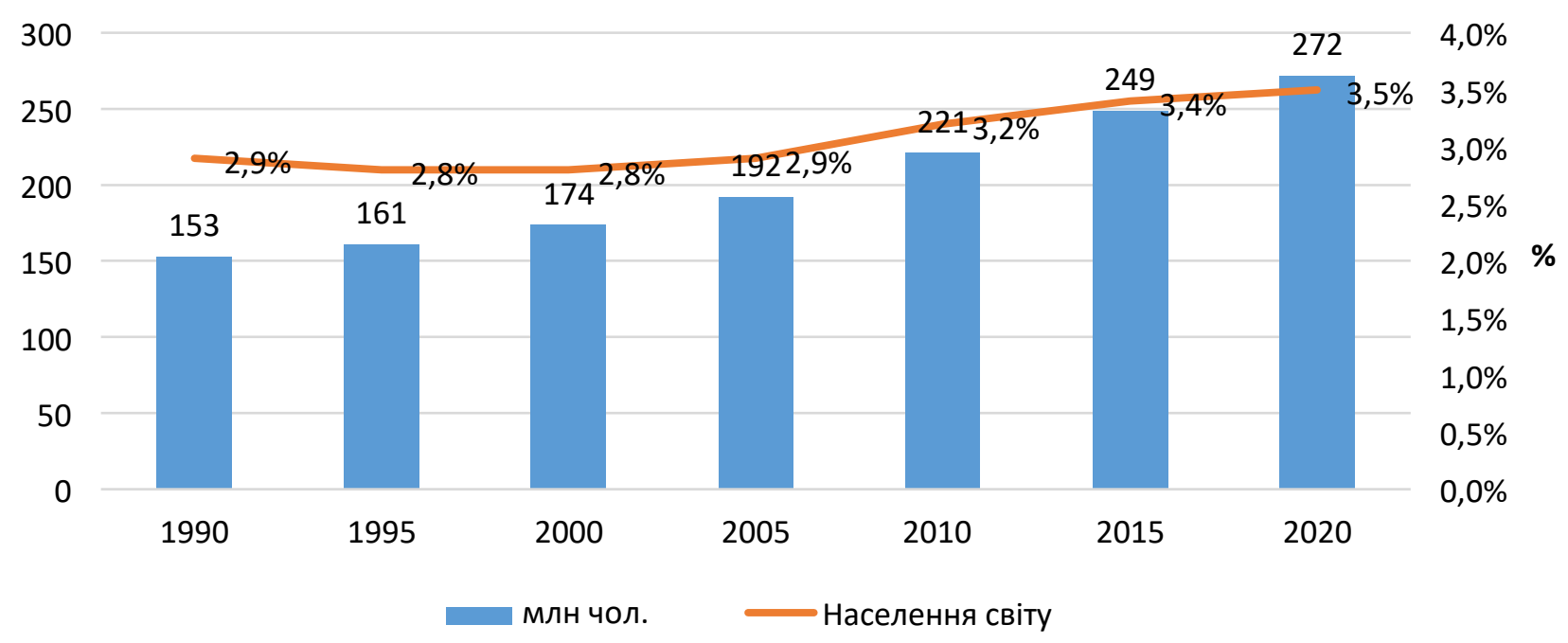

Рис. 5. Кількість міжнародних мігрантів (млн. осіб) та їхня частка у загальній чисельності населення світу (\%) Джерело: [6]

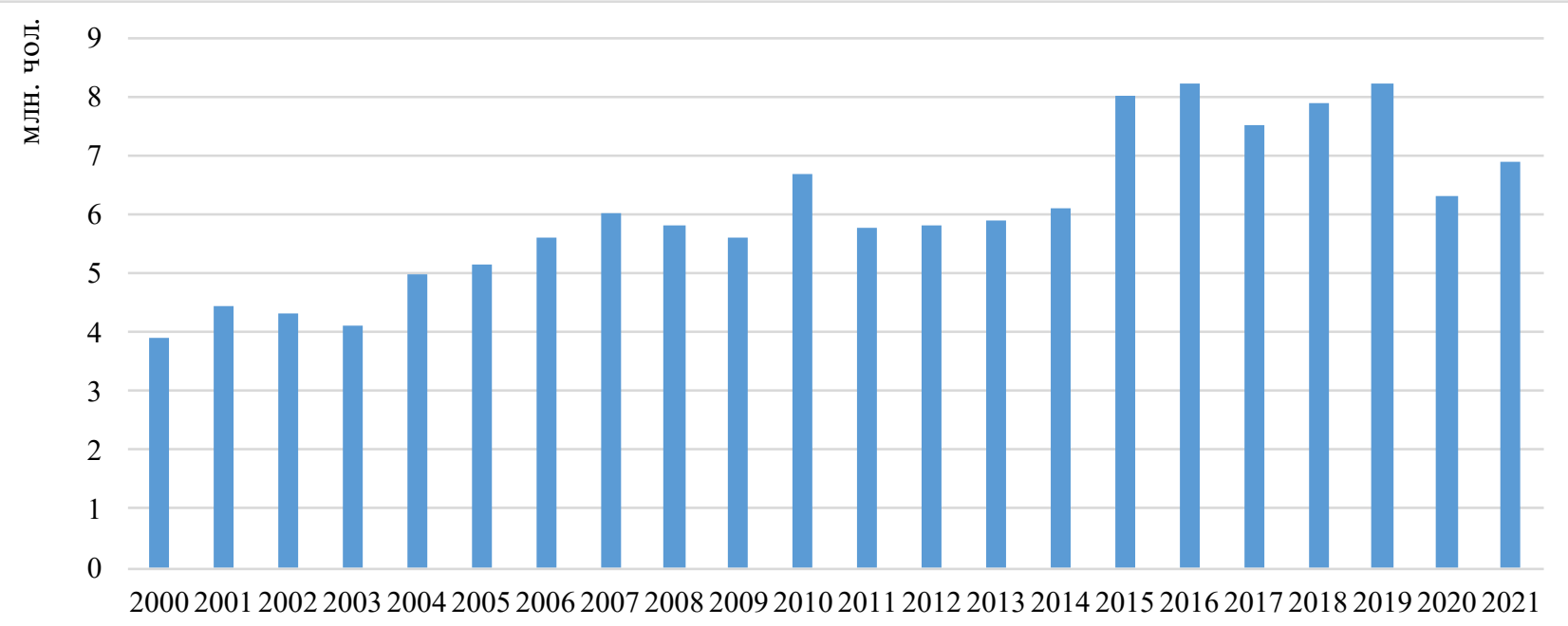

2000200120022003200420052006200720082009201020112012201320142015201620172018201920202021

роки

Рис. 6. Приплив іноземних громадян до країн ОЕСР на постійне проживання, 2000-2021 рр. (у млн осіб)

Джерело: [6] 
на основі статистичних даних, що є на національному рівні. На момент написання цього розділу (серпень 2020 р.) не було оновлень у наборі даних про потоки ДЕСВ ООН, найостаннішою з яких була версія 2015 р. Набір даних про міграційні потоки 2015 р. включає дані щодо 45 країн (лише по 43 країни щодо еміграційних потоків), на відміну від 29 країн у 2008 р. та 15 країн у 2005 р. [9]. Дані ОЕСР 3 міграційних потоків збиралися з 2000 р., що дозволяє проводити обмежений аналіз тенденцій, як показано на рис. 6.

Оцінки дозволяють припустити, що приплив мігрантів до країн ОЕСР на постійне проживання збільшився з 3,85 млн осіб у 2000 р. до 6,8 млн осіб у 2020 р., при цьому під час світової фрінансової кризи відзначалося тимчасове затишшя. Так, у 2020 р. Німеччина залишалася основною країною призначення серед країн ОЕСР, оскільки цього року туди прибуло понад 1,7 млн нових міжнародних мігрантів (більш ніж у два рази більше, ніж було зареєстровано у 2000 р., але менше, ніж 2 млн осіб у 2020 р.), за нею слідують Сполучені Штати (майже 1,2 млн осіб) та Сполучене Королівство (близько 450000 нових мігрантів) [5].

У найрозвиненіших країнах світу проживає переважна більшість міжнародних мігрантів. За 1990-2020 рр. на 69,6 млн. осіб збільшилася чисельність міжнародних мігрантів, що проживають у розвинених країнах (або +84\%), у країнах, що розвиваються - на 44,1 млн. осіб (або $+75 \%)$, у найменш розвинених країнах світу - на 5,2 млн. осіб (або 47\%), (табл. 2).

За аналізований період відбулося зниження частки міжнародних мігрантів, які влаштувалися у найменш розвинених країнах, 3 7,2\% у 1990 до 4,7\% у 2010 р., а до 2020 р. підвищення становило 6,0\% та 38,0\% у менш розвинених країнах світу (рис. 7) [6].

Хоча дані про контингенти мігрантів широко доступні, дані про глобальні міграційні переміщення (потоки) набагато більш обмежені. Наявні оцінки ДЕСВ ООН щодо глобальних контингентів мігрантів великі та глобальні щодо охоплення, однак база даних про міграційні потоки охоплює лише 45 країн. Фіксація даних про міграційні потоки $€$ надзвичайно складним завданням із кількох причин [6].

Значний приріст чисельності міжнародних мігрантів стався у 2005-2010 рр., коли збільшення склало 29,2 млн. осіб (або на 15,2\%), у 2010-2015 рр. - 28,1 млн. осіб (або 12,7\%), у 2020 р. збільшення становило 3,5\%. У 2020 р. розподіл міжнародних мігрантів за місцем проживання виглядав так: 30,8\% - Азія, 30,3\% Європа, 21,6\% - Північна Америка, 4,3\% - Латинська Америка, 9,8\% - Афррика [6] (рис. 8).

Аналіз представлених даних дає можливість визначити зміни, що відбуваються на світовому ринку праці, напрями трудової міграції та фрактори, що впливають на ці процеси, у тому числі пошук роботи мігрантами працездатного віку, можливість отримання високих соціальних виплат у країнах з високим рівнем життя населення (Свідоме отримання статусу безробітного) та ін. [9; 11].

Висновки. Визначено, що чотири демограсрічні тенденції срормуватимуть, при цьому необов'язково визначати, економічну та політичну ситуацію в більшості країн, а також міграційні взаємини між державами. Країни зі значною частиною літнього населення у перспективі можуть прийти до уповільнення зростання сукупного ВВП або навіть застою. Ці країни, пік розвитку яких випаде на пізні-

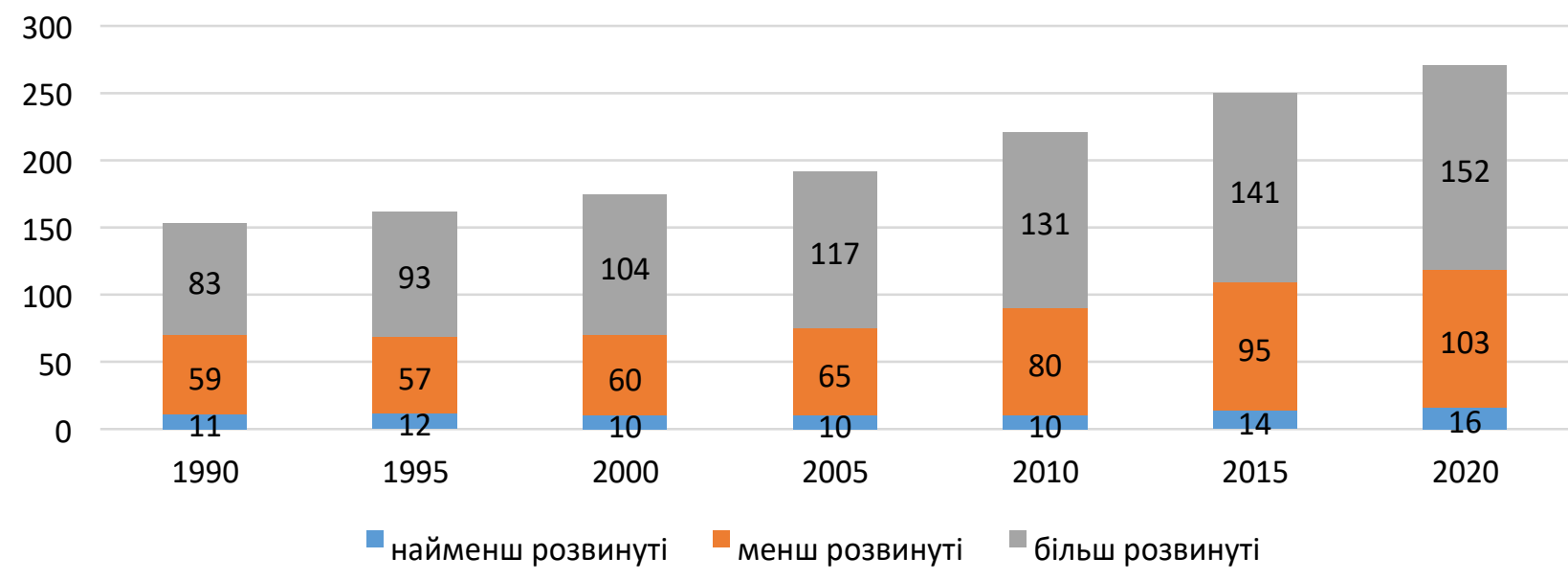

Рис. 7. Кількість міжнародних мігрантів за основними групами країн, млн. осіб Джерело: [10] 


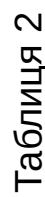

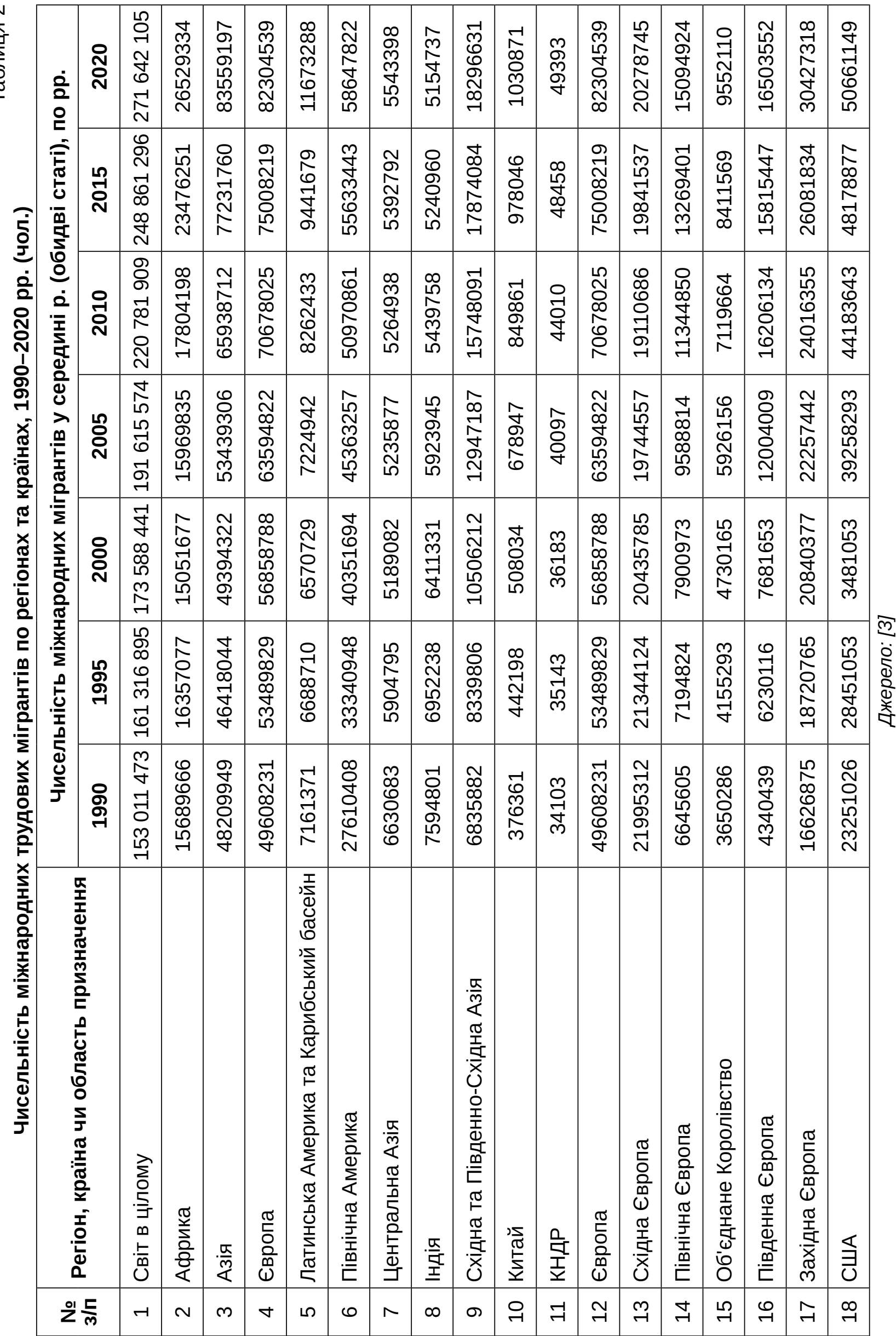




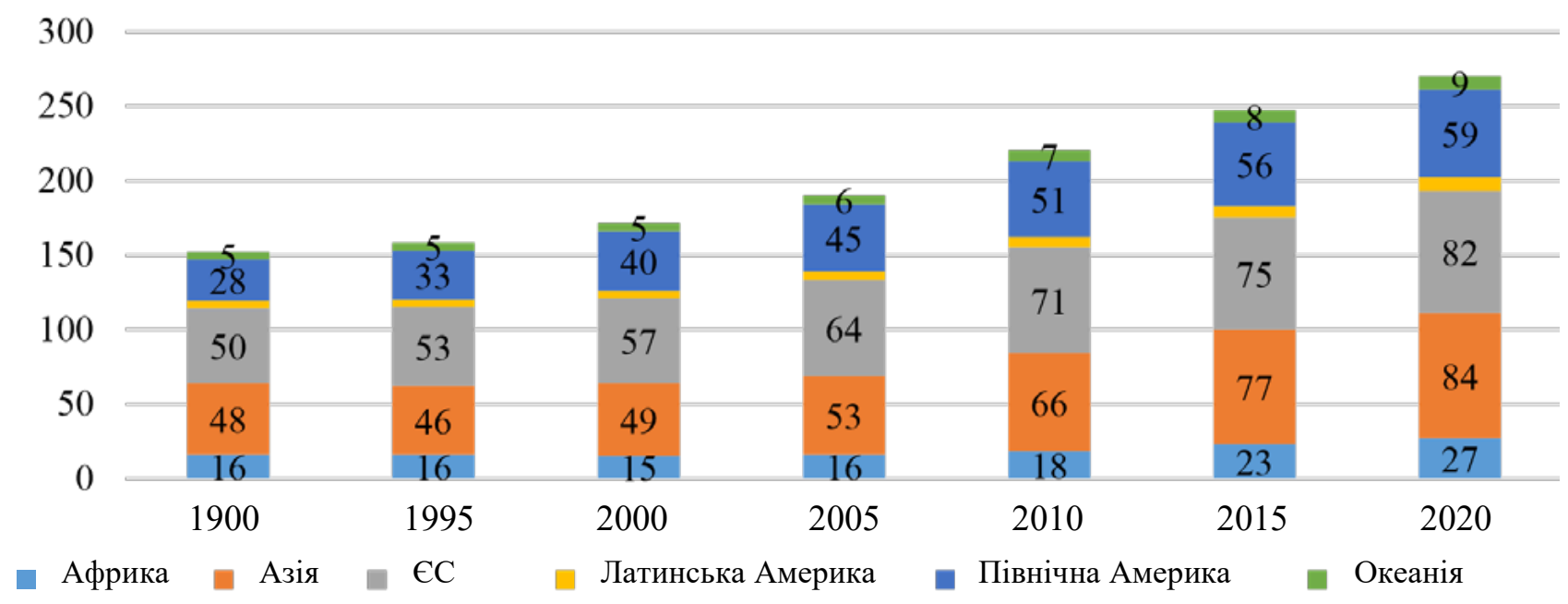

Рис. 8. Чисельність міжнародних трудових мігрантів у регіонах світу, млн. осіб Джерело: [6]

ший період, будуть змушені реалізовувати дорогі програми пенсійного забезпечення та охорони здоров'я, щоб сфрормувати капітал для підтримки пенсіонерів. При цьому збережеться на колишньому рівні якість життя платників податків, які забезпечують пенсіонерів. Відмова від солідарної пенсійної системи та системи охорони здоров'я на користь більш надійно фрінансованих схем може призвести до політичної нестабільності, оскільки уряди намагатимуться підвищити пенсійний вік та спричинити трудову міграцію. Швидка урбанізація стимулює внутрішню міграцію, і її рівень буде навіть вищим, ніж рівень міжнародної міграції.
Доведено, що масове переміщення населення, викликане транссоормацією світового ринку праці, стане основною рушійною силою міжнародної міграції в майбутньому. Багато 3 розвинених держав переживають гостру ксенофоббію та антиіммігрантські настрої, тенденція, яка, здається, зростає. Новою загрозою ринку праці є зростання міграційного потоку з країн Асррики до ЕС і США через значне збільшення народжуваності і кількості населення. У короткостроковій, так і в довгостроковій перспективі, різні групи (високо- або низькоосвічені працівники, власники капіталу, власники будинків, молоді чи старі люди) можуть в різному ступені отримати користь від притоку іммігрантів.

\section{СПИСОК ВИКОРИСТАНИХ ДЖЕРЕЛ:}

1. Бондаревська К. В. Міжнародна міграція робочої сили: стан, проблема, перспективи. Бізнес-Інформ. 2019. № 10. C. 44-49.

2. Main Tables of Labor market statistics. URL: http://epp.eurostat.ec.europa.eu/portal/page/portal/labour_ market/earnings/main_tables

3. Migration and migrant population statistics. URL: http://epp.eurostat.ec.europa.eu/statistics_explained/index. php/Migration_and_migrant_population_statistics

4. Короленко Н. В., Петросян А. А. Міжнародна міграція робочої сили: причини та наслідки. Ефрективна економіка. 2021. № 1. URL: http://www.economy.nayka.com.ua/?op=1\&z=8515 (дата звернення: 20.12.2021).

5. Ушенко Н. В., Покормяк А. С. Міжнародна міграція робочої сили: причинно-наслідковий аналіз. Міжнародний науковий журнал «Інтернаука». 2018. № 2(42). С. 68-72.

6. Total number of long-term emigrants from the reporting country during the reference year. URL: http://epp.eurostat.ec.europa.eu/tgm/table.do?tab=table\&init=1\&language=en\&pcode=tps00177\&plugin=0

7. Македон В. В., Валіков В. П., Кошляк $€$. Є. Світовий ринок праці в координатах цифрової економіки. Академічний огляд. 2020. № 1(52). С. 91-107.

8. Makedon, V., Hetman, O., Yemchuk, L., Paranytsia, N., Petrovska, S. Human resource management for secure and sustainable development. Journal of security and sustainability issues. 2019. № 8(3). P. 345-354.

9. Makedon V., Mykhailenko O., \& Vazov R. Dominants and Features of Growth of the World Market of Robotics. European Journal of Management Issues. 2021. № 29(3). P. 133-141. 
10. Inclusive growth - a high-employment economy delivering economic, social and territorial cohesion. URL: http://ec.europa.eu/europe2020/europe-2020-in-a-nutshell/priorities/inclusive-growth/index_en.htm

11. New Skills for New Jobs. URL: http://eacea.ec.europa.eu/education/eurydice/documents/thematic reports/125en.pdf

\section{REFERENCES:}

1. Bondarevs'ka K. (2019) Mizhnarodna migracija robochoji syly: stan, problema, perspectyvy [International labor migration: conditions, problems, perspectives]. Bisnes Inform, no. 10, pp. 44-49.

2. Main Tables of Labor market statistics. Available at: http://epp.eurostat.ec.europa.eu/portal/page/portal/ labour_market/earnings/main_tables (accessed 21 December 2021).

3. Migration and migrant population statistics. Available at: http://epp.eurostat.ec.europa.eu/statistics_explained/ index.php/Migration_and_migrant_population_statistics (accessed 22 December 2021).

4. Korolenko N. and Petrosian A. (2021) Mizhnarodna mihratsiya robochoyi syly: prychyny ta naslidky [International labor migration: causes and consequences]. Efektyvna ekonomika, [Online], vol. 1. Available at: http://www.economy.nayka.com.ua/?op=1\&z=8515 (accessed 20 December 2021).

5. Ushenko N., Pokormjak A. (2018) Mizhnarodna migracija robochoj syly: prychynno-naslidkovyj analiz [International labor migration: casual relationship]. Mizhnarodnyj naukobij zhurnal "Internauka", no. 2(42), pp. 68-72.

6. Total number of long-term emigrants from the reporting country during the reference year. Available at: http://epp.eurostat.ec.europa.eu/tgm/table.do?tab=table\&init=1\&language=en\&pcode=tps00177\&plugin=0

7. Makedon V., Valikov V., Koshlyak Y. (2020) Svitovyy rynok pratsi v koordynatakh tsyfrovoyi ekonomiky [The world labor market in the coordinates of the digital economy]. Akademichnyy ohlyad, no. 1(52), pp. 91-107.

8. Makedon V., Hetman O., Yemchuk L., Paranytsia N., Petrovska S. (2019) Human resource management for secure and sustainable development. Journal of security and sustainability issues, no. 8(3), pp. 345-354.

9. Makedon V., Mykhailenko O., \& Vazov R. (2021) Dominants and Features of Growth of the World Market of Robotics. European Journal of Management Issues, no. 29(3), pp. 133-141.

10. Inclusive growth - a high-employment economy delivering economic, social and territorial cohesion. Available at: http://ec.europa.eu/europe2020/europe-2020-in-a-nutshell/priorities/inclusive-growth/index_en.htm (accessed 20 December 2021).

11. New Skills for New Jobs. Available at: http://eacea.ec.europa.eu/education/eurydice/documents/thematic_ reports/125en.pdf (accessed 21 December 2021). 